\title{
LIFE HISTORY OF SYNTOMEIDA MINIMA GROTE.
}

\author{
BY HARRISON G. DYAR, NEW YORK.
}

Only recently $I$ had the pleasure of adding this little moth to our fauna (Ent. news, vii, 69) and now I am able to present its life history. The larvae were found at Miami,Florida in December, 1896 , on a creeping plant which looks like a little holly and grows in the pine barrens among the saw palmetto and "coontie." The plant is Myginda ilicifolia, as I learn from Mr. Kinzel. A few moths were seen at the same time, and from them some eggs were obtained. There are five larval stages, occasionally, perhaps often, more, but there is no difference in appearance.

Egg. Sharply conoidal, rather pointed above, narrowed at base; smooth, shining, light ocher yellow, with a very bright pearly white reflection on the side. Shell white, under a half inch objective, lustrous, irridescent, smooth, without reticulations. Diameter .8 , height $.7 \mathrm{~mm}$. Laid singly, or two to seven together on the back of a leaf of the food plant.

Stage I. Light orange, immaculate, smooth, slightly shining, segments distinct; width of head $.5 \mathrm{~mm}$. Setae rather long, blackish, iv and $v$ whitish. On the thorax three setae from a large subdorsal wart and a small one below; a stigmatal and subventral tubercle all normal for the family. On the abdomen $\mathrm{i}$ and $\mathrm{ii}$ normal, large, iii with two setae, ir very small, $v$ rather large, leg plate with several short setae. Subprimary setae all absent.

Stage II. All orange, warts concolorous, small, rather smooth. Hair fine, not dense, in spreading tufts, light slate gray, composed of dark and pale hairs; width of head $.75 \mathrm{~mm}$.

Stage III. Orange, immaculate, the hair thin and gray; head $1.1 \mathrm{~mm}$.
Stage $I V$. Joint 2 retracted; three warts on the thorax. Skin smooth, orange red, irregularly shaded with grayish dorsally and in a distinct, broad, diffuse, subventral band. Warts small, concolorous, grayish in the gray marks, normal, iv absent except on joint 12 , where it is represented by two tiny hairs. Hair not long, thin, not abundant and not concealing the body, slaty gray, growing in small spreading tufts. Head light orange; width $1.7 \mathrm{~mm}$., rounded, scarcely bilobed. Hairs finely simply barbuled, under a lens blackish and pale mixed. There are no tufts or plumes.

Stage $V$. Head rounded, light orange with pale hairs; width 2.t mm. Warts normal for the Euchromiidae except for the absence of wart iv. Ground color of body orange red; a heavy, wide and diffuse dorsal band reaching to wart $\mathrm{ii}$ and a second band from wart $\mathrm{ii}$ to the feet, slightly interrupted around the whitish spiracles, thus making the body dark with a lateral red band. Warts concolorous, dark, rather small. Hairs barbuled, gray, black and whitish mixed, except from wart $i$ and ii above on joints 5 to 12 , where they are darker and thick, almost tufted, forming a series of short, separated, ill-consolidated brushes. Venter and feet orange. Length about $20 \mathrm{~mm}$. There is considerable variation in the amount of blackish shading present in the last stage. One larva spun in the plumage of stage IV.

Cocoon elliptical, composed of hairs and silk, moderately firm, but scarcely opaque; only a few of the hairs sticking straight through.

Pupa uniformly light brown, smooth and shining. 
EDWARDS' BUTTERFLIES N. A.

The plates of the concluding part of Edwards' great work on North American butterflies, are entirely devoted to species of Chionobas, all containing abundant illustrations of the early stages. In the volume now concluded, moreover, Edwards has figured with a wealth of illustrations the complete or almost complete life-histories of no less than a dozen species of this boreal genus, which would seem, from the out of the way places one must reach to find the insect at all, to be the most difficult genus of our butterflies to treat in this way. It is a monument to the author's energy and skill. Numerous sup plementary notes on various butterflies are added to this concluding Part, besides an index to the three quarto volumes now issued. We can but congratulate the author on the handsome completion of his nearly thirty years work, but we wish they were more to come.

\section{PROCEEDINGS OF THE CLUB.}

II December, I896.- The 145th meeting was held at Mr. S. Henshaw's, Mercer Circle, Cambridge, Mr. J. W. Folsom in the chair; Mr. W. L. W. Field was chosen secretary pro tempore.

Mr. S. Henshaw exhibited a specimen of a tropical cockroach (Hormetica sp.), captured in Belmont, Mass.; it is supposed to have been brought north in a bunch of bananas.

Mr. W. L. W. Field told of the capture of a male and female of Libythea bachmani in Milton, Mass., on July 17 and Aug. 9, respectively, by Mr. C. O. Zerrahn; and of the capture of a single battered male of Meganostoma caesonia in Alstead, N. H. on July 25, 1896 by Mr. James A. Field.

Mr. J. W. Folsom exhibited a collection of miscellaneous specimens, mostly spiders and cochroaches, the result of a visit to a banana vessel now discharging her cargo in Boston.

8 January, 1897.- The 196th regular and 2oth annual meeting (since incorporation) was held at ${ }_{15} 6$ Brattle St., Mr. A. P. Morse in the Chair.
The several annual reports were read.

The following officers were elected: President, H. G. Dyar of New York; Secretary, Roland Hayward; Treasurer, Samuel Henshaw; Librarian, Samuel H. Scudder; Executive Committee at large, A. P. Morse and S. H. Scudder.

The annual address of the retiring President, H. S. Pratt, on Imaginal Discs in Insects, was read by S. H. Scudder. (Printed in Psyche for February).

The Treasurer and Secretary were appointed a committee to revise the list of Active Members of the Club.

Mr. A. G. Mayer read a paper on a new hypothesis of seasonal dimorphism in Lepidoptera, which was discussed by Messrs. Scudder, Morse and Folsom, and will appear in full in Psyche.

Mr. S. H. Scudder stated that during a few days collecting on Mt. Desert Isl., Me., in the latter part of August, he only came across 13 different kinds of Orthoptera and none of them were very abundant. On the top of one of the highest mountains, Mt. Sargent (about $1400^{\prime}$ ), Melanoplus mancus and $M$. fasciatus were found, which did not occur below, but $M$. atlanis was common and $M$. femur-rubrum not observed, while at low levels $M$. atlanis was scarce and $M$. femurrubrum common. Besides the latter species, the only common forms at the lower levels were Nemobius fasciatus, Camnula pellucida, Circotettix verruculatus, Stenobothrus curtipennis, Orphula maculipennis, and $M e$ lanoplus femoratus. Hardly a single locustarian was seen and very few indeed heard. The other species noted were Scudderia pistillata, Monotettix cristatus and Chortophaga viridifasciata. Only 7 species of butterflies were seen and insects of all sorts were exceptionally scarce.

Mr. Scudder also stated that he had received from Prof. C. M. Weed the Orthoptera he collected in Bermuda on a recent visit. There were but six species; Labidura riparia, Periplaneta australasiae, Leucophaea surinamensis, Orphula olivacea, Conocephalus fusco-striatus and a species of Gryllus. apparently new. 

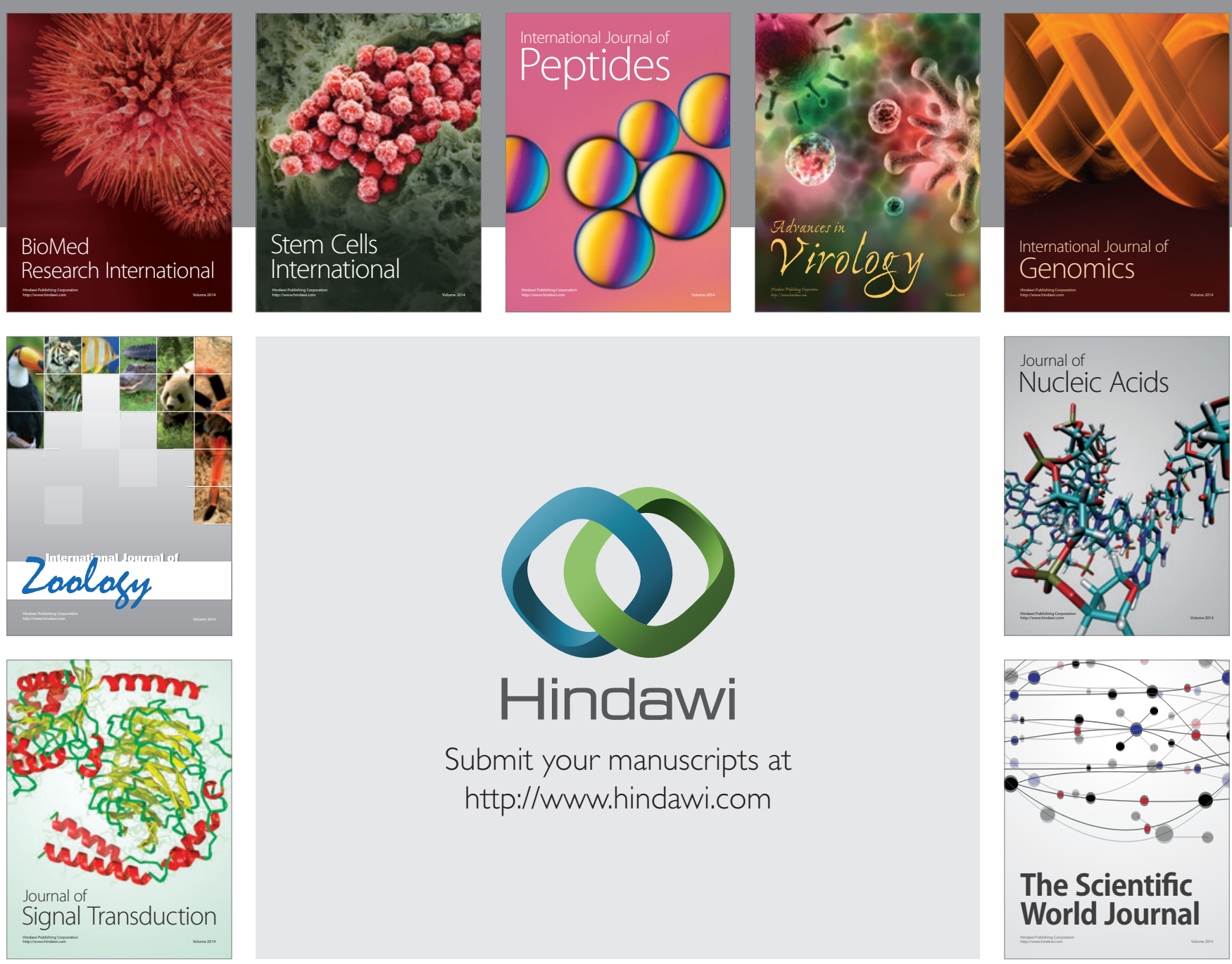

Submit your manuscripts at

http://www.hindawi.com
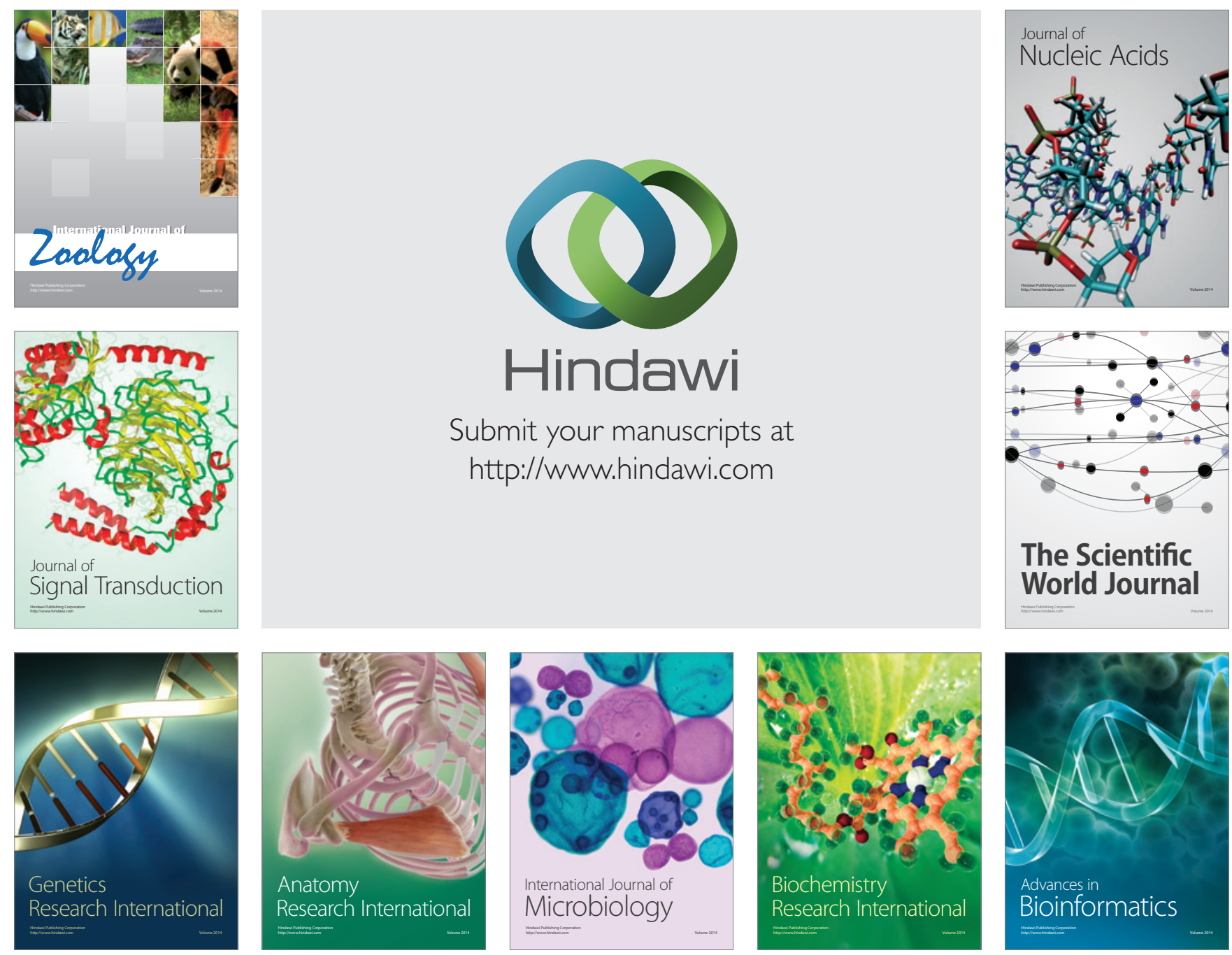

The Scientific World Journal
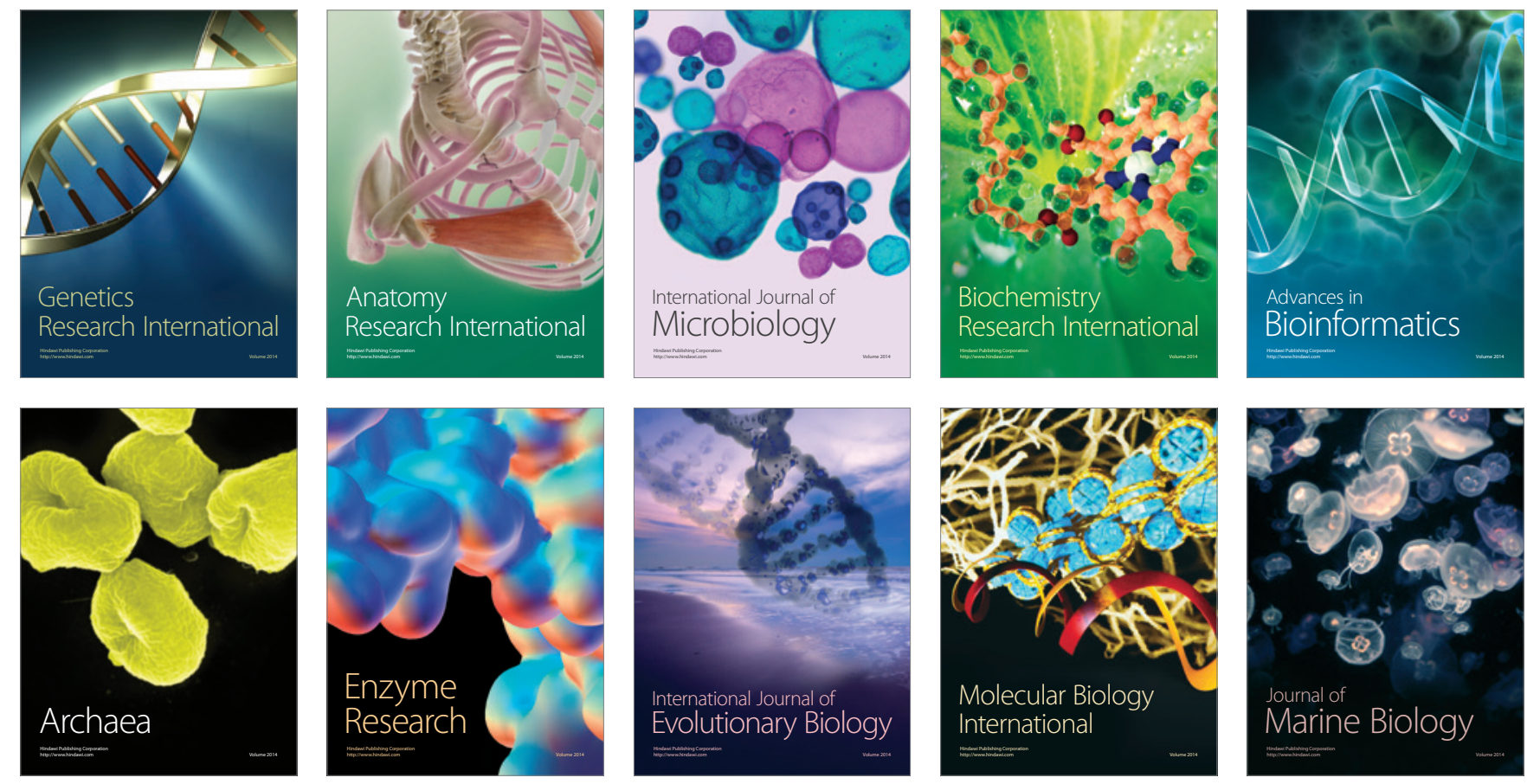